doi no: 10.34074/scop. 1017004

\title{
FASHION FLUID: A PANEL DISCUSSION
}

\author{
Simon Swale, in discussion with Bernadette Casey, Donna \\ Dinsdale, Emily Miller-Sharma, Murray Bevan and Sue Prescott
}

\section{INTRODUCTION}

On Friday 15th March 2019 at the Dunedin Public Art Gallery, Otago Polytechnic School of Fashion staff hosted a fashion symposium as part of iD Fashion Week. Entitled "Fashion Fluid" in keeping with the theme of this journal, the symposium offered a range of presentations by industry professionals, academics and fashion educators. To conclude the day, five guests were invited to form a panel and discuss the future of the New Zealand fashion industry. This panel was comprised of: Bernadette Casey, co-founder and creative director of textile research and sustainable development company The Formary; Donna Dinsdale, Programme Co-ordinator of the fashion department at Toi Ohomai institute of Technology, Tauranga; Emily Miller-Sharma, General Manager of RUBY and designer of the Liam line; Murray Bevan, founder and director of PR and communications company Showroom 22; and Sue Prescott, Programme LeaderFashion at Massey University. The panel discussion was chaired by the author, Otago Polytechnic School of Design fashion lecturer Simon Swale. What follows is an edited version of that discussion. Some editing has been undertaken to add brevity and clarity to the conversation.

'Fashion Fluid' was the second fashion symposium of its kind, following on from the success of 'Metamorphosis' in 2017. 'Metamorphosis' (and the corresponding special issue of Scope: Fashion) had been initiated by Otago Polytechnic Academic Leader of Fashion Dr Margo Barton after many discussions with staff mourning the demise of the not-forprofit organisation Fashion Industry of New Zealand (FINZ). Among many roles, FINZ hosted an annual conference for the fashion/apparel industry and educators to come together, support one another and discuss the general state of sector. Since the demise of FINZ there has been no regular forum for the fashion industry and/or fashion educators to come together. With iD Fashion Week being an annual event on the fashion calendar, moves were made to maximise the opportunity of many educators and industry professionals being in one place at the same time. There seems agreement that discussions such as the one that follows provide networking opportunities and sources of rich knowledge that can be leveraged across the industry by its many stakeholders.

As the panel chair I contacted the panellists to create a framework for our discussion. I referred them to a previous fashion industry panel discussion organised by FINZ and sponsored by international shipping company DHL. Having summarized the main points that I took from that discussion, I provided these to the panellists to reflect upon and to consider as areas we may find useful to pick up on eight years after their initial discussion. Points raised in the 201 I discussion included (I) an emphasis on the speed of change within the fashion industry, and of it becoming a 24/7 environment which never stopped. This necessitated a need to be switched on all the time. (2) The increasing globalisation of fashion and New Zealand's place within that; (3) an increasing focus on exporting and the need to think of Australia as a domestic market to be a viable concern; (4) the importance of branding and the need to build emotional connections with your market. This was seen as essential in creating a point of difference. Finally, (5) the role of the media and the ability of new media to tell stories, for example, 'sneak peaks' backstage at fashion shows through the use of emergent technologies (phone cameras) and technology (such as social media). Interestingly, sustainability did not seem to feature as a major discussion topic, so this was an additional area that seemed an essential talking point. 


\section{'FASHION FLUID' PANEL DISCUSSION}

Simon Swale: I might just start the discussion with Emily; how relevant does the content of the 20 I I DHLFINZ meeting remain in 2019 ?

Emily Miller-Sharma: I think that with the power of new media, we've all become much more exaggerated in what our belief systems are, so I feel like we've gone deeper. We can seek out brands or movements that really resonate with us (unlike through a generic mass media), so when you relate that to us as a clothing company we've had to become deeper and we've had to really understand who we are as humans in the company that we are working in, and who our customers are as humans, so I'm not sure that it completely answers your question but there's something about richness and depth which I think is really important.

SS: I think that picks up on that idea of storytelling and building that emotional connection with your customers.

EMS: Absolutely, and there's always this tension because, to be honest, we (RUBY) are a company and so our job is to be a profitable company, so when we talk about being genuine, there's a tension: "so what is genuine"; there's genuine genuine, and then genuine to the brands, because they are not always two different things but there is a tension that I guess, you are always walking.

SS: It was interesting hearing Kate Sylvester talk at lunchtime, about Kate Sylvester the person and Kate Sylvester the brand; where the boundaries between the two are (or are not). That kind of fluidity, it's quite interesting to think of the way people relate to Kate and her brand.

As the operator of a PR and Communications business Murray, how do you see brands having changed their focus maybe in the last few years and what are they asking of you in your role in PR and marketing?

Murray Bevan: It's been really interesting, the last ten years... there's been this huge saturation of the New Zealand market; overseas brands coming in, local brands starting up It used to be that it was Kate, Karen, World, Zambesi, Trelise and Nom'D- now there's like 50-60 and there's ten new brands that start every year. So what clients are asking of us is of course more for less - because our population is quite small, you don't have the chance to make a lot of money so you see brands like Maggie Marilyn immediately going overseas, Wynn Hamlyn immediately going overseas. They have to really own the New Zealand market, which brands like RUBY- they're getting more of a foothold in retail and they're owning their own conversation, so they're coming direct to the consumer, they've got their own publication channels, they've got their own social media, they've got their own voice which means they don't actually have to rely on the media as much as they used to. So I suppose clients, to answer your question, it's been this crazy sort of chopping up of the industry- many, many, more moving parts. Not as many big media any more, lots of little media, micro influencers, which means you have to get one idea and split it 100 ways to make everyone happy. Then of course as an agency we have to become more creative to satiate the appetite of our designers. It's no longer just a press release and a look book and we just present to them this huge swathe of editorial at the end of the season. We don't use press releases now and look books are just kind of falling flat so we have to create stories and storytelling and exclusives and firsts.

SS: So smaller stories but a lot more of them?

MB: Well probably not smaller stories but fewer stories and deeper stories. I remember when we were launching Juliette Hogan and Kathryn Wilson. A press release sent to 90 people would get you about 50 hits, profile stories, cover pages, sponsorships. These days, I'm constantly in meetings with my staff and we're thinking up 200 new ideas a week, it feels like that anyway, and it's exhausting, it's hard.

SS: That sounds like a massive shift, and very, very quick since 2011 . 
MB: Yeah a pretty big shift. There's been massive job cuts in the media; Fairfax let go of four lifestyle writers two weeks ago so that means that we don't have the chance to proliferate these great stories through fashion and lifestyle media because it just doesn't exist.

I was supposed to give this talk on branding and marketing and PR at one of the fashion schools, and I was like, "right, guys, so here's this case study. who heard about it?" Fourth year students, the most senior students in the school, two people put their hand up. I said, "where do you get your news from?"'They were like, "we just look at the brands we like on Instagram and they just tell us what they are doing" So Viva, which gets 230,000 readers a week, is redundant to young people... don't try and target a 20 year old because they are just not reading the paper.

SS: You talk about some of the people you employ in your team and I wonder, where are they coming from? Are they coming from fashion schools, or are you getting people from business programmes, how do you recruit? I'm leading to fashion education, and whether we teaching the right stuff?

MB: We recruit from a really narrow pool of people who are obsessed with an extremely small industry, which is fashion PR, which is why we are one of the only groups of people that do what we do in this tiny country. Pretty much we go through social media and ask, would you like to come and work with us? So yeah, it's fashion students but you can take someone from any industry; our best staff member was an architecture graduate with a Masters. Her only fashion experience was that she worked retail at Moochi, but she just said, "I've always wanted to work here, I came here for a school visit when I was in seventh form and l've never forgotten about this place." She was the last interviewee I had and I was like, "it's yours." But we need good people; I can't exist or grow my business just with fashion PR in New Zealand, we have to do water, beer, cars, hotels, events, gifting, sponsorships.

SS: And I guess that's the reality of fashion today that it really transcends all parts of culture to a certain degree.

EMS: Thinking about fashion transcending culture and about fashion education. When I studied I learned that during times of the plagues, the baby doll line was really popular for women to wear because it made them appear as if they were pregnant, even if they weren't. So that for me was like, "Woah! clothing and society are intricately linked", and that for me was learning to think as a student, but then there is still a need for a well cut pair of pants. That is a skill as well and that's a different skill and I think that both are really, really important. Especially for us in our business model, we require a lot of hands on, we have internal pattern makers, we cut all our own samples, we've just employed a sample machinist and so we require that technical skill as well as the thinkers; both skills are important.

SS: Absolutely. Let us hear from a fashion educator; Donna?

Donna Dinsdale:I think that's our challenge, the integration of creative practice, of being innovative, of expecting our students to constantly have idea generation, and those technical skills, you're right in saying, are just as important. But something's got to give, and we find it quite difficult to deliver creative thinkers alongside technical expertise and so we are always discussing at Toi Ohomai the relationship between those two things and how we can manage that and it's not easy, and hence that's why we are here (at this forum), wanting to get some feedback.

EMS: One of my favourite things when I was at university was pattern making, but actually my technical skills, especially from a construction perspective but also a pattern making perspective, came when I was in a workroom because you have to sew ten of the same collars in a row to learn how to sew a collar and you need to be doing it for weeks on end and you also need to be doing it when you're been paid, and you sit there at the sewing machine and that is all you are doing for that day or that week or that month, or that six months. So I am in the process of trying to set up an industry body, and the long term vision for that would be around working in partnership with institutions to make apprenticeships a thing, because you know, our pattern maker is 55, and she has trained so many people on just like basic, basic pattern manipulation and there is something so valuable about that. 
Most of our production department have come from being interns. Our sample machinist was an intern, she was just really good at sewing, and she finished university and it was like, "you like sewing, you're really good at it, do you want to be our sample machinist", like we haven't had an in house sample machinist before but we really wanted one, and she's like, "yep l'll give that a go", and she's just kind of rolled with it.

DD: Because within an educational environment we can only deliver and teach so much. It's a bit of a bubble really- it's not the real world, but we expect our students to have outcomes so they need to know how to do those technical things on certain levels.

Sue Prescott: In education it's hard to fit in all these things and you're not going to produce an expert in every field because you are constantly bringing in new things, and nothing drops off because you've been used to this quality that you've been producing in your students and you don't want to let that go. But at the same time you're bringing in huge levels of innovative thinking and critical thinking and all kinds of other things that make our students go forward into a multidisciplinary world.... About internships, a lot of the time they do learn on the job. Often that's a non-paid internship, (which is another issue, and we probably won't even go there just now,) but it means that those internships are only available to students that can afford to do that, it's not really to be considered education at that point because some just can't afford to go and live in Auckland for four months, you know, which is a real issue to us, and I know it's something that's been looked at not just in New Zealand, in terms of the unpaid labour.

EMS: As of this year our interns are paid. We've actually just started doing an internship programme, maybe two school holidays ago, in our store, and I know this is a little off topic, but just on interns, I just love it, it's really cool, we have high school students during their holidays, they can intern in our retail stores and they're paid, so they are paid minimum wage, but it's the concept of, it's really hard as a 16 year old to get experience if you have no experience, so that's kind of the thinking.

SS: There's a lot of focus on sustainability today and so it's another aspect within fashion education, and how do we address that? - what do you think is the starting conversation we should be having with students?

SP: In education? It should be in there full stop. It can't not be in there. There are universities, like Parsons and others, where you can go and do a sustainable fashion degree, but it can underpin everything you do. Once upon a time, you might say, "oh I think I'm going to do a sustainable collection"," woah, edgy!", but now it would be an expectation with the information that's available, and the impact that we see and feel, it should just be in there- they should be thinking of systems, looking at supply chain. We take students to India and we go and study just that, we do lots of workshops for weeks in lots of different parts of India, and we do collaborations with Indian students and our students come back very wise as a person, you know, and go on to do things after that but I think it's something that should just be underpinning everything. Obviously we're a fashion department, but it's across the design school that they are looking at sustainability, it's not just in fashion.

DD: I think a lot of the students coming through now are really informed and ethically, they're really onto it and there is an expectation to step up to that and I think hearing how how sustainable practice has been put into real life situations is really important for educators.

Bernadette Casey: We're often invited to guest lecture at universities and what we are finding is that we're increasingly being asked by intermediate schools and primary schools if they can come and visit our operations because the education is starting much younger, as we can see down in the Octagon today (where school students took to the streets in as part of the international 'Strike 4 Climate Change' movement). They're far more aware.

SS: Just thinking about a systems based approach which we talked about quite a lot with Bernadette and whether there is a need to petition government to make change. There's often discussion about how we as an industry are such a small part. It's great that an individual does their bit, but do we as a body, as an industry, need to petition the government to make a greater impact? 
BC: Before I did my master's research in ethical purchasing I thought yeah, it is the individual's responsibility, and after completing my research I stepped away from that position. With the Intergovernmental Panel on Climate Change (IPCC) report saying we've got a dozen years to address this issue, we've got a really condensed timeframe and for individuals, it's virtually impossible to navigate how ethical a brand is just by reading their reports. We're seeing things, like the Fixing Fashion report from the audit and ethics committee of the House of Commons that came out just a couple of weeks ago, recommending that it's policy not individual choice that is going to make the difference and the issue around climate change is so massive that we are going to need those polices to protect society, to protect people's wages, to protect the environment etc., so I think that's where we're heading.

MB: concerning too much information- if you look to the Baptist World Aid Tear Fund report. Fashion labels get stamped with this mark, the public doesn't really care to read about why, they just nail them to the wall if it's bad and that sucks because lots of good brands get taken to task and they shouldn't be.

SP: People believe what they read and may not think "how does that accreditation process work and how many people in this company was there to put that great case forward to get an A+ rating", Because then there is this company that is a bit smaller, just as good but didn't have that personnel or resources behind them. There's no discussion about that and it's a really important factor when you are reading things like those results.

EMS: Can I add to that, thinking about scale and how you can actually affect change as an individual company, which is really limited, especially in a country like New Zealand. As New Zealand labels we are small within the clothing industry, so our ability to affect real change on our own is limited, but if we're working together it's much more powerful. We've been working with the team at Kate Sylvester and what we've really learned is the need to be sharing supplier information in order for us to know what we are working with. So it's a big project but Kate and I, we're trying to work on this larger industry thing because there is actually a genuine need for it.

BC: We've seen that kind of collaboration coming through with the Textile Reuse Programme. We've got Alsco, Barkers, Deane Apparel (who is New Zealand's largest uniform supplier), and uniform purchasers, and because they are around the table together they are starting to share that knowledge but also because it is such a massive problem not one individual company is going to be able to solve it on their own and that's why I think we've moved to a space where collaboration is becoming more natural.

EMS: And that's what we're aiming with this network. The first stage is that all of the members of the network have to, of their New Zealand supply base, give the details of their machinists, their pressers, their pleaters, their fabric agents, and then, basically a questionnaire for each of the companies to fill out, how many staff do you have, where is your premises, etc., From there, working with an independent company to assess the risk baskets around New Zealand manufacture and to set some reasonable benchmarks, which are not necessarily the same as what a CMT factory's benchmarks would be in China or in Vietnam. Usually our CMT factories would be anywhere between 3 and 15 staff, so what do we reasonably expect from an employer of three staff, to have trained their staff in terms of joining a union, what is a reasonable expectation in the New Zealand fashion industry for our local makers? That is literally what we are trying to do.

I do believe through the designers that we've been speaking with, I feel like there is a tipping point and there's a realisation that if we don't do something radical, we are all a bit stuffed. It's a sort of slow shift but it is actually shifting.

SS: That leads me to ask about new business models. Are young designers operating in a different way to traditional models?

MB: Fundamentally no; I think they've all got to have a customer, they've got to have collections. Maybe they are tightening up on their seasonality and not doing the traditional two collections a year.l think it's probably more in the branding, the marketing, the social media, the reliance on media. Marketing budgets are almost non-existent. Some labels still spend an eye-wateringly large amount on advertising a year but their customer responds to that- they 
are older and read magazines, but the young designers are way more nimble. They'll activate something overnight, they'll push it on Instagram tomorrow, it will be done by the next day and then they will move on. Others wouldn't be able to get their heads around that, their way of thinking is so engrained in the old school. But no, fundamentally the businesses have to be based on profit and loss, and not making too much stuff and not buying too much fabric and not having too many staff. One thing l've seen is that lots of those older companies made their way up from nothing; they are self-made, and a few of the new ones are probably funded, that's a new thing.

EMS: Yes, 'cos you need cash. I mean your point about profit and loss, stock management; that is literally it! Yes, absolutely businesses are changing from a marketing perspective, but fundamentally you don't want to be holding onto too much stock because then you've got no cash and you can't buy new stock. That hasn't changed.

MB: One thing we are seeing is that few of the new designers have gone into their own retail stores quickly. So you look at previous generations, there was no such thing as online, so you had to have a door that opened and jeans inside the door. So now you've got Georgia Alice, Maggie Marilyn, Wynn Hamlyn- no retail, Harman Grubisa one tiny store, and it's like a war to keep a store afloat.

SS: Is it worth it today?

MB: I don't know; can you survive online? A lot of them are doing it, the turnover is not huge but you can expand overseas, so do you then go and get an overseas agent quickly, PR, sales, push yourself in New York, become the designer du jour and all of a sudden you're on Net-a-Porter.

Maggie's gone there, Georgia's gone there, Wynn's only started to go there now, Harman Grubisa went there and they got catapulted by winning the regional Woolmark Award, the first time ever a Kiwi designer has won that.

SS: I was thinking of Courtney Pellow, who l'd never heard of, I don't know who she is, but she's a Kiwi kind of gaining momentum off one Instagram post where Kendell Jenner is wearing her clothing. To me that's "...wow". That undoubtedly garnered her a lot of visibility.

MB: I don't know how she did that but you look at a raft of different brands here who get international exposure on celebrities. When Madonna wore Karen Walker's pants at the MTV awards it sold so many thousands of units of those trousers - the public dined out on it for ages. Now, Gigi Hadid wears something on one Instagram post from a Kiwi designer and an hour later the media are going "next, what else you got"... maybe a spike in sales but then the consumer's also like, "I hate her, next".

But probably Karen, more than anyone, has been a trailblazer pushing New Zealand fashion overseas and has spent many, many years doing it and man it's a hard slog, but now she going "it's about my own media, my own stores, my own channel, my social media"- she can sell hundreds of units of a product in a weekend just with one Instagram post and the media don't even get wind of that, and then it's gone, so she's been able to stay pretty much at the head of the curve which is changing and winding and everything, super quick.

SS: Thinking back to the DHL forum which was in $201 \mathrm{I}$ - the year after Instagram launched. It's amazing how fast Instagram has become so influential.

EMS: Yesterday Instagram was down and we had some new product going into store and our marketing exec, she was in our showroom, she was taking some photos of the product to post on Instagram and she was kinda like, "I don't really know what to do"- it was a really weird thing for her.

MB: Yesterday, someone in my office said "imagine if Instagram and Google and everything was down for a year, what would we do?" I said "see that thing next to your computer, that's called a phone. You pick that up and you go and have meetings with people- it would be fine". But people forget that some of the best communication you can 
have, the most binding, the most loving, the most lasting, is actually taking someone out for a cup of coffee, or sitting down with them, across the table and saying, "I've got this story for you." And then they go, "really, me, wow... you thought about me?"You don't get that with a press release.

SS: To the educators: have you noticed a change in the students coming through and the manner of their creativity? Now that social media is so entwined with their lives, do you think it has changed their creativity, or the way they think creatively?

DD: Yeah, it has had an impact. I was thinking about the discussion around collaboration. We teach in a collaborative environment, there's a lot of open spaces, there's a lot of working across, and what we're finding is the students are demanding that those collaborations are there; thinking creatively beyond your discipline or your major to enhance what you are doing and what you produce, and that comes with social media. Now that's just a given.

SS: It's part of that connectedness with other people?

SP: It's the real world. But I think in terms of creativity, the students are very quick to pick up the phone and go onto Pinterest or something, and I'm thinking, "no, no- this idea has to be born into your brain first, just have some thoughts, don't be looking for somebody else's precedent first. They seem to be forgetting how to originate thinking, and I think that is really, really important.

DD: For us within education, those collaborations that our students have are really, really important, and this is what education needs also, you know, we should all be talking with industry, because we're all in the same gig, we're passionate about fashion.

SP: We have tried in the past, when I first came to New Zealand, there was a board that was set up between education and industry but we just couldn't fund it. It lasted about two years.

SS: I wonder, is there any real or perceived disconnect between what students are learning in their education and what they actually need in the industry.

EMS: Can I say, one of the greatest things that l've taught our team is maths- we do a lot of profit and loss training at work. It's big concepts for a lot of people when they first start learning about it but there is an aspect to it across the board, not just fashion. That's an aspect l've really noticed.

Then there's the apprenticeship model that I really truly believe is what shores up our manufacturing industry here and when I say manufacturing, I'm talking about bulk production and I'm talking about pattern making, bespoke making as well, for me those are two really big opportunities.

DD: Having the right forums to share and to get feedback is so important, because what we're delivering and the content that we hope to deliver is driven by industry; we're training the future, and so for us, we have to have that feedback, we need it.

FINZ was a great way for educators to all meet, to get industry and speakers together. So I'm really thrilled about this symposium, but I feel we need more of it. We need relevance, and we need to maintain currency with the fast pace of change.

\section{CONCLUSION}

While the above conversation highlighted the significant changes the industry has faced in the relatively short amount of time since the FINZ/DHL discussion of $201 \mathrm{I}$, it also highlighted how prescient some of those focus points were. Especially concerning the changes in fashion communication born out of technological developments, 
social media has in many ways come to dominate the fashion experience. This has, of course, exacerbated the industries incessant desire for change and for the new and which is now governed by an increasing sense of speed.'

It are these very facts that have perhaps been responsible for the rapid rise in focus for ethical fashion practices by increasing numbers of consumers. The concern for issues of sustainability have seen the conversation move from the margins, to becoming a central concern for consumers and businesses alike. In part, social media has provided a platform for consumer critique that can quickly go viral, so that today brands face an increasing expectation from consumers for transparency of their supply chains on their websites. As always, technological develops remain both a boon and a curse...

Whatever changes technology brings, it seems evident that these will only increase the prevalence of the mediated fashion experience.There is an increasing- seemingly unrelenting, demand for fashion media content and experiences outside the traditions of fashion from previous generations. This is just one area which fashion educators must remain attuned in the development of their programmes. Other areas of increasing importance are the need for graduates to be both skilful and knowledgeable in their chosen field, but also flexible, adaptable and capable of operating in increasingly diverse workforces and situations. Collaboration is nothing new to the way the fashion system operates, but there nonetheless remains a certain focus on the heroic designer model- if only in the minds of some students. It seems inevitable however that the future will become increasingly interdisciplinary and that creative practitioners will need to display competencies to work across industries rather than being grounded in any one speciality. At the same time, and as mentioned above, aspects of the industry are becoming increasingly fragmented, with a much greater number of roles required to maintain even a small start-up operation. It is both an unnerving situation and an exciting opportunity for fashion education. One where the ground feels to be constantly shifting beneath ones feet, but which also offers the potential to propel and witness change in a field which we are all so passionate about.

Along with all fashion staff at the School of Design, Otago Polytechnic, I would like to warmly thank all presenters at the 'Fashion Fluid' symposium, and particularly, the members of this panel discussion. Further thanks go also to the Research Office of Otago Polytechnic for providing funding for the 'Fashion Fluid' symposium and for supporting us to bring Bernadette and Murray to Dunedin. Transcription services for this discussion were provided by Paula Petley- thank you Paula. Thanks also to the Dunedin Public Art Gallery for providing the venue.

Simon Swale (100000-0002-5830-3034) is a Senior Lecturer in Fashion at the School of Design, Otago Polytechnic, Ke Kura Matatini ki Otago. Simon spent many years working in the local fashion industry before taking up a role at the polytechnic where he has since developed research interests in the relationship between fashion and identity, and more recently fashion and art.

I S Swale, "Speed, Technology, Entrophy:The Fashion System at Breaking Point," Scope:Art \& Design, I 5:2 (20 I7), I 39-45, https:// www.thescopes.org/art-and-design- I 5/speed-technology-entropy-the-fashion-system-at-breaking-point/. 